\title{
ROTI, PEMILIHAN BAHAN DAN PROSES PEMBUATAN
}

\author{
Ni Putu Decy Arwini \\ Program Studi Teknik Industri, Fakultas Teknik, Universitas Mahendradatta Bali \\ Jl. Ken Arok No 12, Peguyangan Denpasar Utara, Bali 80115 \\ Email: decyarwini@yahoo.co.id
}

\begin{abstract}
Abstrak - Roti adalah sebuah penganan sumber karbohidrat yang dianggap sangat praktis untuk kehidupan masa kini yang serba cepat dan praktis. Banyak kaum milenial sarapan pagi hanya dengan roti dan susu atau teh. Begitu juga dengan makan malam. Rasa yang enak dan beragam, bentuk yang unik tanpa mengurangi kandungan gizi didalamnya menjadi alasan utama mengapa roti menjadi sebuah pilihan utama dalam menu sehari-hari.

Bahan dasar pembuatan roti adalah tepung, air, ragi, garam, gula, lemak, susu, telur dan bread improver. Tepung merupakan bahan dasar pembuatan roti. Tepung dibedakan berdasarkan kandungan glutennya. Air digunakan sebagai pelarut dari berbagai bahan yang digunakan dalam adonan roti. Selain itu, air juga digunakan sebagai pengontrol suhu. Ragi digunakan sebagai pengembang agar roti mempunyai tekstur yang lembut. Gula digunakan sebagai penambah rasa. Lemak digunakan untuk membuat roti yang dihasilkan menjadi lembut dan tidak lengket di loyang. Telur bermanfaat untuk menambah kandungan protein dan membantu proses pengembangan adonan. Sedangkan bread improver digunakan sebagai bahan tambahan untuk mengawetkan roti.

Proses dalam pembuatan roti terdiri dari pengadukan bahan yaitu pencampuran bahan-bahan yang digunakan dalam komposisi yang tepat. Proses kedua yaitu peragian untuk mendapatkan tekstur roti yang mengembang. Selanjutnya adalah proses pembentukan. Langkah terakhir adalah pemanggangan.

Roti memiliki nilai ekonomis yang tinggi dan juga dapat dikerjakan oleh industri kecil. Berbagai macam varian yang ada dengan nilai jual terjangkau dapat membantu meningkatkan perekonomian masyarakat
\end{abstract}

Kata kunci: Roti; Bahan; Proses

Abstract - Bread is one of carbohydrate source that is suitable for this practical life. A lot of millenial's have their breakfast just with bread combined with milk or tea. So does with dinner. Variety of taste and shape makes bread is one of important menu af our daily.

The ingredients of the bread are wheat, water, yeast, salt, sugar, fat, milk, egg and bread improver. Wheat is the basic ingredient for the bread. There are many kind of wheat depend on prosentage of the gluten in the wheat. Water is used to dissolve all the ingredients for the bread and also for temperature control. Yeast is used to cake developer so the bread will have a perfect texture. Sugar is used to add some taste, fat is used to make the bread soft and not sticky in the pan or oven. Egg is used to add some protein and bread improver au used to preserves the bread.

The first process to make a bread is mix the ingredients, then fermentation, formation and the last process is roast the bread.

Bread has a high economic value and even a small industry can make a bread. Many bread varian with a cheap prise could improve economy of the community.

Key word: Bread; Ingredients; Process

\section{PENDAHULUAN}

Roti adalah sebuah penganan sumber karbohidrat yang dianggap sangat praktis untuk kehidupan masa kini yang serba cepat dan praktis. Secara definitif, roti adalah makanan yang terbuat dari tepung terigu yang diragikan dengan ragi roti dan dipanggang. Kedalam adonan roti dapat dtambahkan berbagai tambahan pelezat seperti coklat, kismis, selai beraneka rasa dan lain sebagainya. Banyak kaum milenial sarapan pagi hanya dengan roti dan susu atau teh. Begitu juga dengan makan malam. Rasa yang enak dan beragam, bentuk yang unik tanpa mengurangi kandungan gizi didalamnya menjadi alasann utama mengapa roti menjadi sebuah pilihan utama dalam menu sehari-hari. 


\section{KAJIAN PUSTAKA Sejarah Roti}

Roti pertama kali berkembang di zaman kebudayaan Mesopotamia di wilayah Mesir 10.00-12.000 tahun yang lalu. Wilayah ini memiliki perkebunan gandum sebagai salah satu bahan makanan utama saat itu. Pada masa inilah tepung gandum ditemukan pertama kali dan mendorong pengolahan lebih lanjut atas tepung tersebut menjadi roti seperti yang dikenal sekarang. Perkembangan roti di Mesir kemudian menyebar hingga ke Yunani sampai akhirnya merata di seluruh daratan Eropa. Dari masa kebudayaan Mesir sampai sekarang, roti telah mengalami perkembangan sangat pesat seiring dengan penemuan dibidang teknologi yang membantu pengolahan roti. Perkembangan tersebut juga disesuaikan dengan kondisi geografis dimasing-masing daerah sehingga seluruh dunia memiliki roti khas masing-masing seperti Roti Canai di India, Roti Pita di Timur Tengah dan Tortilla di Meksiko.

Roti juga menjadi penanda status sosial masyarakat pada jaman dahulu. Roti yang berasal dari tepung putih sangat sulit didapatkan dan harganyapun sangat mahal sehingga yang mampu mengkonsumsinya hanyalah kalangan mampu saja.. semakin hitam roti yang dihasilkan maka harganyapun semakin murah.

\section{JENIS-JENIS ROTI}

Seiring perkembangan jaman, ada beberapa jenis roti yang dikenal sekarang. Roti tersebut antara lain:

a. Roti gandum

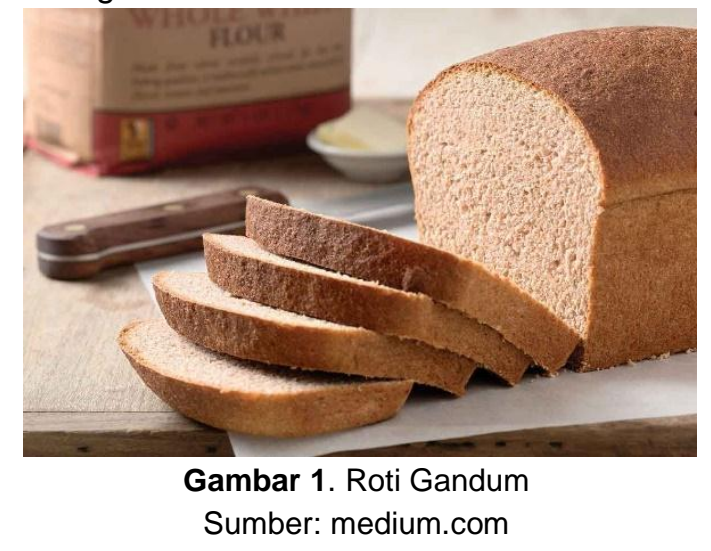

Roti gandum banyak diproduksi di Australia dan Amerika. Roti gandum merupakan roti bertekstur kasar dengan warna coklat. Jenis roti ini kaya akan serat dan warna coklatnya berasal dari serealin yaitu lapisan sel yang terdapat pada sereal. Kandungan serat yang banyak pada roti gandum sangat baik untuk menu diet. Roti gandum cocok disandingkan dengan salad, baik sayur ataupun buah

\section{b. Baguette}

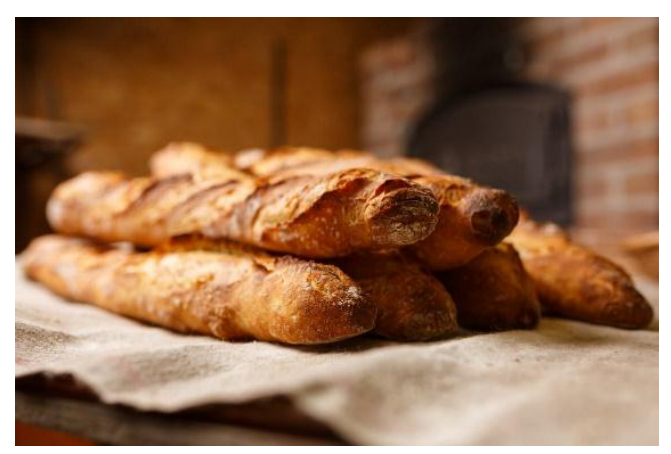

Gambar 2. Baguette

Sumber: medium.com

Baguette adalah roti tradisional Prancis yang memiliki panjang hingga mencapai 50 $\mathrm{cm}$. Roti ini juga dikenal dengan nama roti tongkat. Roti ini memiliki kulit keras, berwarna coklat dan bagian dalamnya banyak terdapat lubang-lubang. Baguette biasanya diiris tipis-tipis lalu disajikan dengan sup atau dipanggang dan diberi aneka macam topping sesuai selera.

\section{c. Croissant}

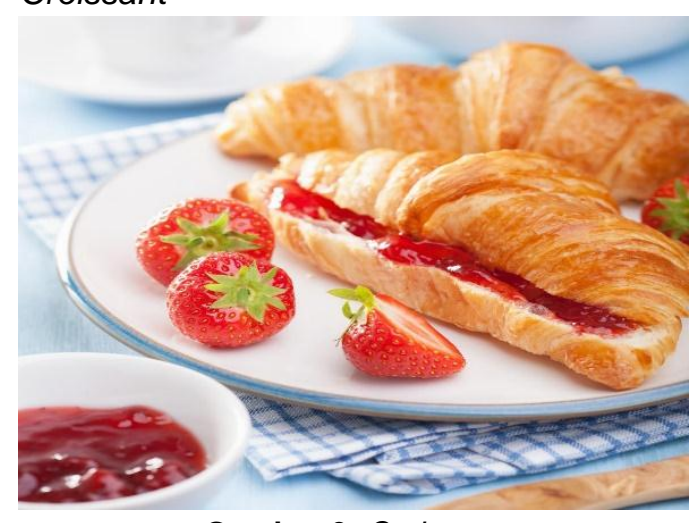

Gambar 3. Croissant

Sumber: medium.com 
Croissant juga berasal dari Prancis. Croissant berbentuk mirip bulan sabit. Roti ini dibuat dari adonan berlapis, teksturnya renyah, dan empuk. Croissant biasanya disajikan saat sarapan dengan diolesi mentega dan selai buah.

\section{d. Bagel}

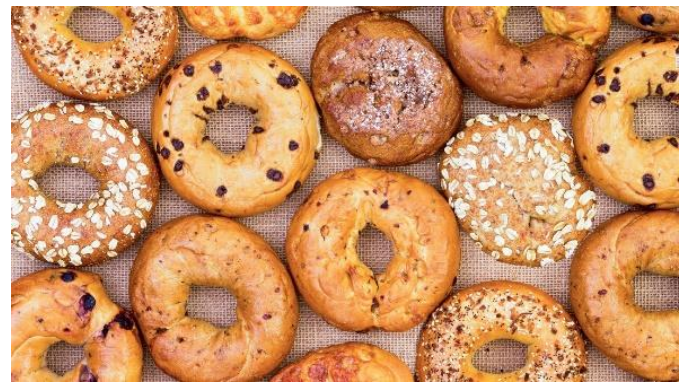

Gambar 4. Bagel

Sumber: medium.com

Bagel adalah roti khas dari Eropa Timur yang bentuknya bulat seperti donat, tapi bagian dalam lebih padat. Bagel disajikan pada saat makan pagi, dibelah, dibakar dan diolesi keju krim. Pada adonan bagel biasanya ditambahkan kismis, blueberry, bawang, atau wijen.

e. Crumpet

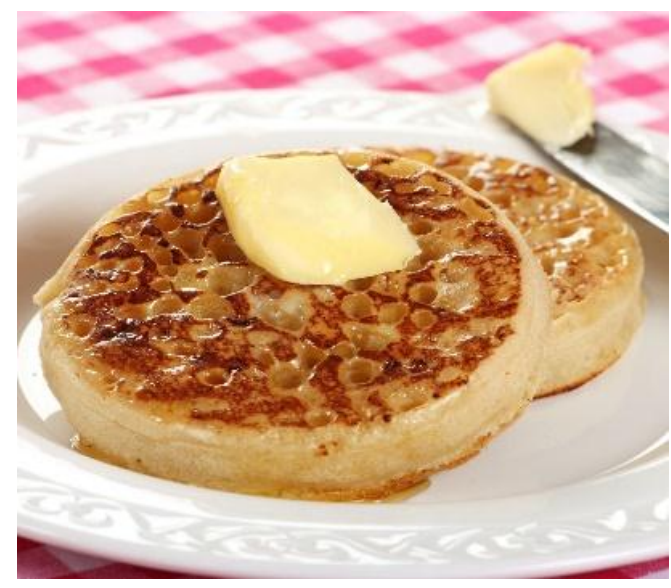

Gambar 5. Crumpet

Sumber: medium.com

Crumpet adalah sejenis roti muffin namun teksturnya lebih lembab dan berasal dari Inggris. Crumpet sering disajikan dengan diolesi krim padat atau mentega dan dimakan pada saat minum teh. Sebelum dihidangkan, roti ini biasa dipanggang atau dibakar terlebih dahulu

\section{f. Corn Bread}

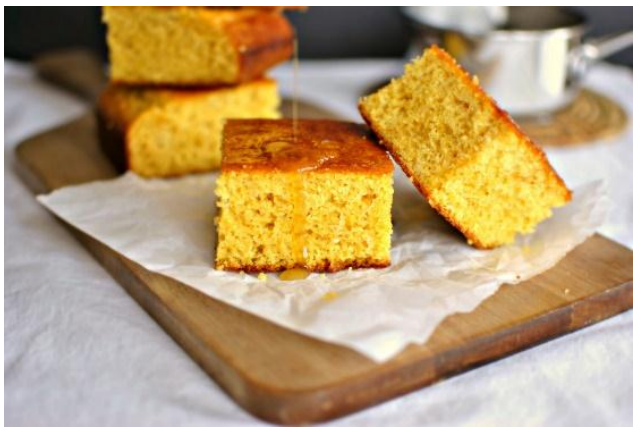

Gambar 6. Corn bread Sumber: medium.com

Sesuai dengan namanya, jenis roti ini merupakan roti yang terbuat dari jagung. Melihat bahan dasar tersebut, corn bread memiliki banyak kandungan nutrisi yang baik bagi tubuh. Corn bread cocok dimakan sendiri sebagai camilan atau sarapan dengan rasanya yang manis. Corn bread berasal dari Amerika

\section{g. Sourdough}

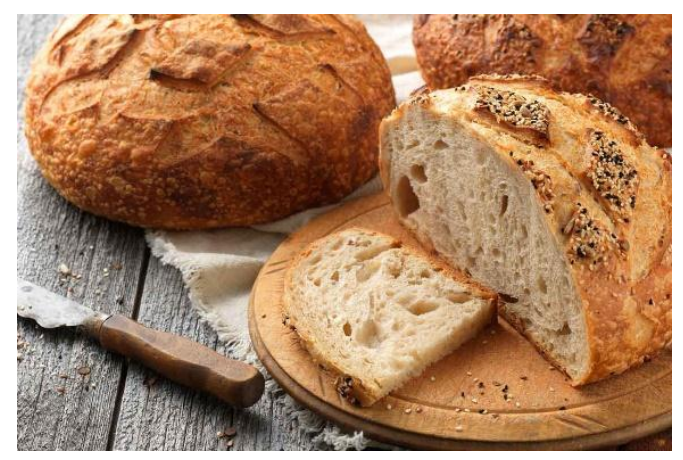

Gambar 7. Sourdough

Sumber: medium.com

Sour berarti asam, sedangkan dough berati adonan. Jadi bisa diartikan Sourdough adalah jenis roti yang memiliki rasa masam. Sourdough menggunakan ragi khusus yang mampu memunculkan cita rasa unik asam tersebut. Sourdough sangat pas untuk dinikmati dengan hidangan laut. Sourdough sendiri merupakan roti khas San Fransisco, Amerika 
h. Pita

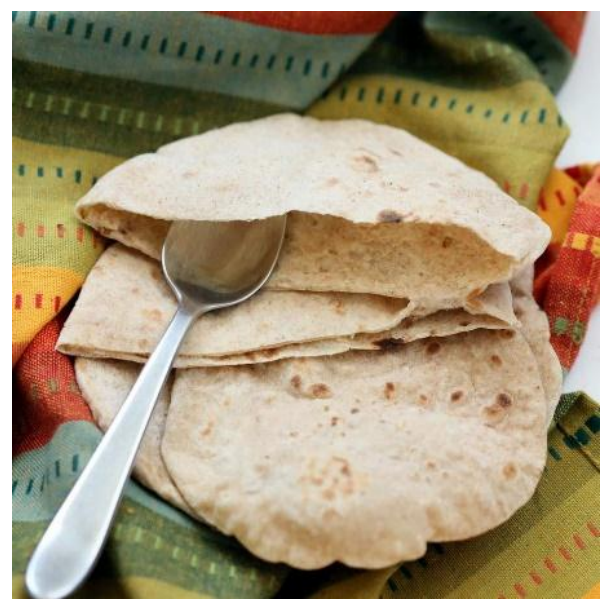

Gambar 8. Pita

Sumber: medium.com

Roti Pita bentuknya bulat dan pipih, disebut juga Roti Arab karena dikonsumsi mayoritas oleh penduduk Timur Tengah. Pita memiliki tekstur yang kenyal dan lembut. Pita terbuat dari adonan puff dan dipanggang dalam oven bata dengan suhu sekitar $232^{\circ} \mathrm{C}$. Pita memiliki rasa yang cukup hambar dengan bagian tengah yang kosong sehingga cocok dimakan bersama berbagai jenis hidangan mulai dari asin hingga manis. Pita biasanya disajikan dengan kombinasi keju, meses, selai, kare, gulai, atau susu manis

\section{Pengertian Produksi}

Produksi adalah proses pengubahan bahan baku menjadi barang jadi atau juga sebagai menambah nilai pada suatu produk (barang dan jasa) agar bisa memenuhi kebutuhan masyarakat.

\section{Teori Proses Produksi}

Proses produksi adalah suatu kegiatan yang menggabungkan berbagai faktor produksi yang ada dalam upaya menciptakan suatu produk, baik itu barang atau jasa yang memiliki manfaat bagi konsumen. Adapun beberapa tujuan proses produksi adalah sebagai berikut: Untuk menghasilkan suatu produk (barang/ jasa).

\section{METODOLOGI PENELITIAN}

Dalam penelitian ini, data yang digunakan adalah berupa primer yang diperoleh langsung dari proses pembuatan roti rumahan dan juga data sekunder yang diperoleh dari literaturliteratur yang berkaitan dengan materi jurnal. Berikut flowchart alur penulisan jurnal ini.

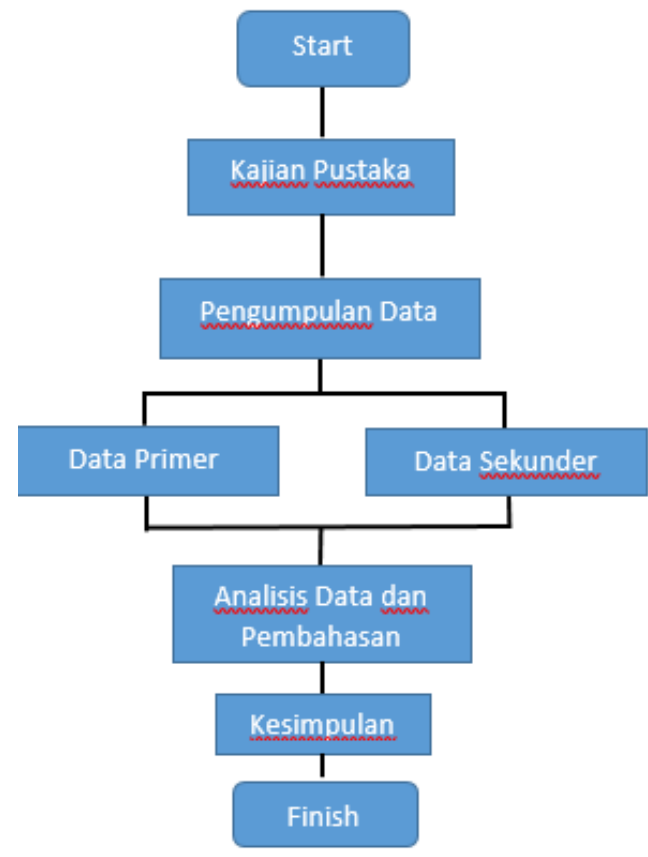

Gambar 9. Alur Penelitian Sumber: Analisis Pribadi

\section{HASIL DAN PEMBAHASAN Bahan-Bahan Pembuatan Roti}

Roti adalah makanan berbahan dasar utama tepung terigu dan air, yang difermentasikan dengan ragi, tetapi ada juga yang tidak menggunakan ragi. Namun kemajuan teknologi manusia membuat roti diolah dengan berbagai bahan seperti garam, minyak, mentega, ataupun telur untuk menambahkan kadar protein di dalamnya sehingga didapat tekstur dan rasa tertentu. Roti termasuk makanan pokok di banyak negara Barat.

Bahan baku untuk proses pembuatan roti dapat digolongkan menjadi tiga kelompok. Kelompok pertama adalah bahan pokok atau bahan utama seperti tepung terigu, ragi dan air. Selanjutnya adalah kelompok bahan penambah rasa yaitu gula, garam, lemak dalam bentuk 
shortening, mentega atau margarin, susu dan telur. Kelompok ketiga adalah kelompok tambahan berupa mineral yeast food (MYF), malt, dan emulsifier, yang berfungsi untuk meningkatkan mutu adonan (dough improver) dan pengawet terutama terhadap jamur.

\section{Tepung}

Tepung biasanya dipergunakan untuk keperluan rumah tangga, bahan baku industri, maupun keperluan penelitian. Tepung bisa berasal dari bahan nabati, misalnya tepung terigu dari gandum, tapioka dari singkong, lalu maizena dari jagung. Tidak hanya dari bahan nabati saja, tepung juga bisa berasal dari hewani, misalnya tepung tulang dan tepung ikan. Berdasarkan kandungan glutennya, tepung yang digunakan dalam pembuatan roti dapat dibedakan menjadi:

\section{Tepung protein rendah}

Memiliki kandungan protein sebanyak 5 sampai $9 \%$ yaitu kandungan gluten terendah dibandingkan dengan jenis tepung yang lain. Tepung jenis ini sangat cocok digunakan untuk membuat jenis adonan yang membutuhkan tekstur kenyal dan elastis. Sangat baik bila digunakan unutk membuat anekan jenis kue kering, biskuit, gorengan dan lain sebagainya.

2. Tepung protein sedang

Memiliki kadar protein 9,5 sampai $11 \%$. Dalam masyarakat sering disebut sebagai tepung serba guna karena sangat cocok digunakan dalam berbagai kebutuhan pembuatan aneka jenis makanan yang memiliki jenis tekstur lembut dan mengembang seperti kue basah, pancake, martabak dan lain sebagainya.

3. Tepung protein tinggi

Memiliki kadar protein 11,4 sampai $14 \%$ yaitu kandungan gluten tertinggi dibandingkan dengan tepung yang lain. Tepung protein tinggi digunakan untuk adonan yang memerlukan tekstur yang kenyal dan elastis dan dalam prosesnya biasanya menggunakan ragi sebagai bahan tambahan. Tepung inilah yang sering digunakan sebagai bahan baku pembuatan roti, donat, mie, pasta dan lainnya.

4. Tepung self rising
Biasanya digunakan oleh para ahli masak yang telah memiliki keahlian karena jenis tepung ini memiliki harga yang lebih mahal dan telah dicampur dengan pengembang dan garam sebelumnya. Yang harus diperhatikan adalah masa kadaluarsa jenis tepung ini yang lebih cepat bila dibandingkan dengan jenis tepung lainnya. Jenis tepung ini biasanya digunakan untuk membuat muffin, pancake dan lain sebagainya

5. Tepung gandum utuh (whole wheat flour) Dibuat dengan menggiling biji gandum utuh tanpa menghilangkan kulitnya sehingga warna dari tepung ini cenderung agak kecoklatan dan memiliki tekstur yang agak kasar, tidak seperti tepung jenis lainnya. tepung gandum utuh memiliki kadar protein yang tinggi, sehingga sangat menyerap cairan dan kaya akan serat. Hasil makanan yang menggunakan jenis tepung ini biasanya akan lebih berat, padat dan memiliki cita rasa yang khas serta unik. Tepung gandum utuh biasanya digunakan untuk membuat aneka roti dan kue kering.

\section{Ragi}

Bahan wajib yang harus ada dalam proses pembuatan roti adalah ragi (yeast). Ragi adalah mikroorganisme yang masih termasuk dalam kelompok jamur yang mampu hidup di tanah, tumbuhan maupun diudara bebas. Sourdough adalah adonan tepung yang tidak sengaja terfermetasi oleh wild yeast di Mesir lebih kurang 3000 tahun yang lalu. Inilah awal mula roti yang banyak diminati masyarakat dunia saat ini. Yeast atau mirkoorganisme ragi alami ini memakan gula dan pati tepung, sekaligus mengolahnya menjadi karbondioksida. Proses inilah yang membuat roti mengembang. Dalam pembuatan roti, ada tiga jenis ragi yang paling popular yaitu:

1. Ragi basah (fresh yeast)

Umumnya berbentuk halus dan padat. Biasanya dibentuk balok dan dibungkus alumunium foil. Ragi basah mudah rusak sehingga harus disimpan dalam keadaan beku.

2. Ragi aktif kering (active dry yeast)

Ragi jenis ini lebih tahan lama daripada ragi basah. Ragi ini perlu diaktifkan terlebih 
dahulu dengan melarutkannya dalam air dan gula. Jika muncul gelembung-gelembung dari larutan ragi, berarti mikroorganismenya sudah hidup kembali dan ragi siap digunakan

3. Ragi instan (instant yeast)

Bentuk ragi instan lebih halus daripada ragi aktif kering. Hanya saja, daya tahannya tidak sekuat ragi aktif kering. Jika kemasan sudah dibuka, ragi instan harus segera dipindah ke dalam wadah kedap udara. Ragi jenis ini tidak perlu diaktifkan lagi dengan air dan gula. Ragi instan bisa langsung dicampur ke adonan tepung

\section{Air}

Air berfungsi sebagai campuran pada tepung terigu sehingga membentuk adonan. Proses pencampuran air dengan tepung membentuk gluten yang sifatnya elastis dan dapat dibentuk. Air juga berfungsi sebagai pengontrol suhu adonan. Hal ini sangat penting untuk diperhatikan karena jika adonan menjadi panas saat pengadukan di mixer, dapat terjadi proses fermentasi lebih cepat namun pembentukan gluten untuk memperkuat struktur roti tidak sempurna, sehingga waktu simpan hasil olahan roti menjadi pendek. Air yang digunakan untuk pencampuran adonan lebih baik menggunakan air es untuk mencegah terjadinya proses fermentasi yang cepat.

\section{Garam}

Garam berfungsi sebagai pengontrol dan penstabilisasi rasa pada roti, pengontrol proses fermentasi dari ragi juga sebagai pengawet alami pada roti

\section{Gula}

Gula berfungsi sebagai penambah rasa juga penambah warna kecoklatan pada roti. Selain itu, warna kecoklatan dari proses pemanggangan dapat membentuk kerak luar yang menambah tekstur pada roti. Penambahan gula pada adonan roti juga dapat meningkatkan umur simpan roti.

\section{Lemak}

Lemak yang digunakan pada proses pembuatan roti tergolong beragam seperti butter, mix butter dan shortening. Lemak tersebut memiliki fungsi yang sama, hanya saja rasa dan gizi pada butter tersebut berbeda. Fungsi dari penambahan lemak pada roti adalah sebagai pelembut pada roti, sebagai pelumas pada adonan roti sehingga adonan lebih mudah dibentuk, juga sebagai tambahan gizi pada roti.

\section{Susu}

Penambahan susu pada proses pembuatan roti bertujuan untuk meningkatkan nutrisi pada roti. Namun, pada proses pembakaran, terdapat aroma lezat yang dikeluarkan karena penambahan susu, selain itu tekstur remah pada roti menjadi lebih lembut.

\section{Telur}

Fungsi penambahan telur sebagai penambah nutrisi dan gizi juga melembutkan tekstur roti

\section{Bread Improver}

memiliki fungsi sebagai pengawet yang aman bagi roti sehingga umur simpan roti lebih lama, melembutkan remah roti, menambah volume pada roti dan pengontrol masuk dan keluarnya gas saat proses fermentasi berjalan

\section{Proses Pembuatan Roti}

Dalam pembuatan roti, ada beberapa tahapan yang harus dilakukan yaitu:

a. Pencampuran

Secara tradisional ada dua cara pencampuran adonan roti, yaitu:

1. sponge and dough method atau metode babon

Dalam metode babon, sebagaian besar tepung dan air, semua ragi roti dan garam mineral serta zat pengemulsi dicampur menjadi babon. Babon difermentasi selama 3-6 jam, kemudian dicampur dengan bahan lainnya.

2. straight dough method atau cara langsung,

Proses straight dough lebih sederhana tetapi kurang fleksibel, karena tidak mudah dimodifikasi jika terjadi kesalahan dalam proses fermentasi atau tahap sebelumnya. Dalam proses ini seluruh bahan dicampur sekaligus menjadi adonan sebelum difermentasi 
3. no time dough

seluruh bahan dicampur sekaligus, adonan langsung dibentuk atau masuk ke dalam alat pencampur tanpa fermentasi

4. metode babon cair yang disebut juga brew atau broth

Pada pembuatan babon cair, $25 \%$ tepung dibuat babon cair sebelum pencampuran adonan

Tujuan pencampuran adalah membuat dan mengembangkan sifat daya rekat gluten tidak ada dalam tepung. Tepung mengandung protein dan sebagaian besar protein akan mengambil bentuk yang disebut gluten bila protein itu dibasahi, diaduk-aduk, ditarik, dan diremas-remas.

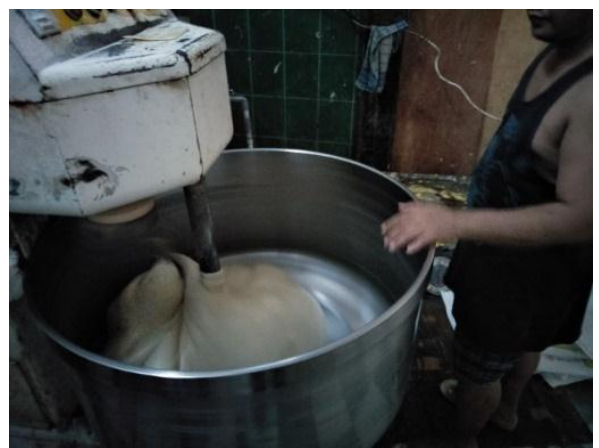

Gambar 10. Pencampuran bahan Sumber: dokumentasi pribadi

b. Peragian

Tujuan fermentasi (peragian) adonan ialah untuk pematangan adonan sehingga mudah dibentuk dan menghasilkan produk bermutu baik. Selain itu fermentasi berperan dalam pembentukan cita rasa roti. Selama fermentasi enzim-enzim ragi bereaksi dengan pati dan gula untuk menghasilkan gas karbondioksida. Perkembangan gas ini menyebabkan adonan mengembang dan menyebabkan adonan menjadi lebih ringan dan lebih besar. Suhu normal untuk fermentasi adalah kurang lebih $26^{\circ} \mathrm{C}$ dan kelembabannya $70-75 \%$.

c. Pembentukan

Pada tahap ini secara berurutan adonan dibagi dan dibulatkan, diistirahatkan, dipulung, dimasukkan dalam loyang dan fermentasi akhir sebelum dipanggang dan dikemas. Pembagian adonan dapat dilakukan dengan menggunakan pemotong adonan. Proses berikutnya adalah intermediete proofing, yaitu mendiamkan adonan dalam ruang yang suhunya dipertahankan hangat selama 3-25 menit. Di sini adonan difermentasi dan dikembangkan lagi sehingga bertambah elastis dan dapat mengembang setelah banyak kehilangan gas, teregang dan terkoyak pada proses pembagian. Setelah didiamkan adonan siap dengan pemulungan. Proses pemulungan terdiri dari proses pemipihan atau sheating, curling, dan rolling atau penggulungan serta penutupan atau sealing. Setelah pemulungan adonan dimasukkan ke dalam loyang yang telah dioles dengan lemak, agar roti tidak lengket pada loyang. Selanjutnya dilakukan fermentasi akhir, yang bertujuan agar adonan mencapai volume dan struktur remah yang optimum. Agar proses pengembangan cepat fermentasi akhir ini biasanya dilakukan pada suhu sekitar $38^{\circ} \mathrm{C}$ dengan kelembaban nisbi 75 $85 \%$ Dalam proses ini ragi roti menguraikan gula dalam adonan dan menghasilkan gas karbondioksida

d. Pemanggangan

Beberapa menit pertama setelah adonan masuk oven, terjadi peningkatan volume adonan secara cepat. Pada saat ini enzim amilase menjadi lebih aktif dan terjadi perubahan pati menjadi dekstrin adonan menjadi lebih cair sedangkan produksi gas karbondioksida meningkat. Pada saat suhu mencapai sekitar 76 oC, alkohol dibebaskan serta menyebabkan peningkatan tekanan dalam gelembung udara. Sejalan dengan terjadinya gelatinisasi pati, struktur gluten mengalami kerusakan karena penarikan air oleh pati. $\mathrm{Di}$ atas suhu $76{ }^{\circ} \mathrm{C}$ terjadi penggumpalan gluten yang memberikan struktur crumb. Pada akhir pembakaran , terjadi pembentukan crust serta aroma. Pembentukan crust terjadi sebagai hasil reaksi maillard dan karamelisasi gula. 


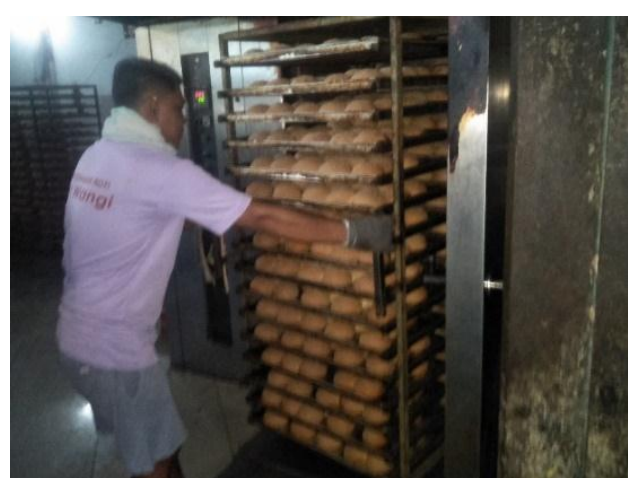

Gambar 11. Penyimpanan Roti Sumber: Dokumentasi Pribadi

\section{Mutu Roti}

Roti dinyatakan bermutu tinggi jika memenuhi berbagai persyaratan maulai dari pemilihan bahan baku berkualitas, proses pengolahan yang baik yang tidak mengurangi nilai gizi komponen penyusun roti, proses pengemasan, proses penyimpanan dan distribusi hingga kepelanggan yang tepat waktu. Namun pada dasarnya, mutu roti sangat ditentukan oleh:

1. Mutu Adonan

Mutu adonan dalam pembuatan roti sangat tergantung kepada kandungan gluten tepung. Gluten akan menentukan mutu adonan, volume pengembangan adonan dan sangat menentukan penampilan roti yang dihasilkan, khususnya dalam pembentukan struktur crumb.

2. Mutu roti

Mutu roti yang baik meliputi volume roti yang besar, bentuk yang simetris, warna kerak roti yang coklat kekuningan, tekstur kerak yang tipis dan kering, serta sifat sifat bagian bagian roti yang meliputi butiran dan tekstur. Butiran yang baik adalah butiran dengan sel yang halus, seragam yang panjang-panjang, sedangkan tesktur yang baik adalah yang halus lembut dan elastis. Selain itu struktur remah harus rata, warna remah terang, beraroma harum gandum dan ragi dengan rasa dan daya simpan yang baik.

\section{SIMPULAN DAN SARAN Simpulan}

Dari pemaparan diatas, dapat ditarik beberapa kesimpulan yaitu:

1. Roti adalah makanan olahan yang terbuat dari tepung yang ditambahkan dengan bahan-bahan lain sehingga memiliki kandungan karbohidrat sebagai sumber tenaga

2. Proses pembuatan roti yang baik awali dengan pengadukan, peragian, pembentukan dan pemanggangan

\section{Saran}

Dari penelitian yang telah dilakukan, maka saran yang bisa diberikan antara lain:

1. Roti memiliki pangsa pasar yang sangat baik sebagai bahan makanan pokok karena memiliki kandungan karbohidrat dan protein yang tinggi sehingga memiliki prospek bisnis yang cukup baik kedepannya. Penjualan dapat ditingkatkan dengan menambah varian roti dengan dasar adonan yang sama dan topping yang berbeda

2. Industri roti dapat dikerjakan secara modern ataupun manual, sehingga masyarakat secara individupun mampu mendapatkan peluang bisnis melalui produksi roti

\section{DAFTAR PUSTAKA}

https://www.maxmanroe.com/vid/bisnis/pengerti an-produksi.html https://id.wikipedia.org/wiki/Roti

Joko, Sri. 2004. Manajemen Produksi dan Operasi. UMPress. Malang

Koswara, Sutrisno. 2009. Teknologi Pengolahan Roti. Ebookpangan.com. Jakarta

U.S Wheat Associates. 1981. Pedoman Pembuatan Roti dan Kue. Djambatan. Jakarta 